\section{Micropropagation of an Endangered Medicinal and Indigenous Multipurpose Tree Species: Erythrina abyssinica}

\author{
Margaret W. Kirika \\ Department of Biochemistry and Biotechnology, Kenyatta University, P.O. \\ Box 43844, Nairobi, Kenya, Africa
}

Jane W. Kahia ${ }^{1}$ and Lucien N. Diby

ICRAF Côte d'Ivoire Country Program, Côte d'Ivoire, Cocody Mermoz 08 BP 2823 Abidjan 08, Côte d'Ivoire

\author{
Eliud M. Njagi \\ Department of Biochemistry and Biotechnology, Kenyatta University, P.O. \\ Box 43844, Nairobi, Kenya, Africa
}

Colombe Dadjo

Pan African University Institute for Basic Sciences, Technology and Innovation, JKUAT-Juja Campus, PO Box 62000-00200, Nairobi, Kenya

Christophe Kouame

ICRAF Côte d'Ivoire Country Program, Côte d'Ivoire, Cocody Mermoz 08 BP 2823 Abidjan 08, Côte d'Ivoire

Additional index words. Erythrina abyssinica, microshoot, medicinal, nodal explant

\begin{abstract}
Erythrina abyssinica (E. abyssinica) is a multipurpose tree and a well-known medicinal plant which is conventionally propagated mainly by seeds. This method may produce a high degree of genetic variability and consequently decrease the medicinal value of the plant. Besides, the seeds have low germination rate and propagation is restricted to rainy season. Hence, there is need to develop a propagation protocol which produces a uniform plants and one which is not restricted to seasons. The objective of this study was to establish an in vitro propagation protocol for the multiplication of $E$. abyssinica. Seeds were sterilized and germinated in vitro to get sterile starting explants. Sterilization of the seeds was evaluated using different concentrations of a commercial bleach (JIK) ranging from $10 \%, 20 \%$ to $30 \%$ for 25 minutes. Kinetin $(2.25,4.50,6.75$, and $9.0 \mathrm{mg} / \mathrm{L})$, and benzylaminopurine (BAP; 2.15, 4.30, 6.46, and $8.61 \mathrm{mg} / \mathrm{L}$ ) were evaluated in separate experiments for their effect to induce microshoots from nodal explants. Rooting of the microshoot was carried out using half strength Murashige and Skoog (MS) media supplemented with indolebutyric acid (IBA) $(0.20,0.51$, and $1.02 \mathrm{mg} / \mathrm{L})$. Statistical analysis software (SAS) package was used to perform analysis of variance on the data to test the significance of the difference between treatments. The result of the sterilization experiment indicated that $10 \%$ JIK gave the highest percentage $(55 \%)$ of clean seeds. Benzylaminopurine evaluated at $8.61 \mathrm{mg} / \mathrm{L}$ gave the highest mean number of microshoots $(6.80 \pm$ 1.24) after 28 days. On the other hand, IBA evaluated at $0.51 \mathrm{mg} / \mathrm{L}$ gave the highest mean root length $(6.00 \pm 01.85 \mathrm{~cm})$. The regenerated plants were acclimatized in the greenhouse and $65 \%$ survival rate was recorded after one month. With the increasing worldwide demand for medicinal plants as an alternative to prescription drugs, ex situ, in situ conservation programs and true to type mass propagation of $E$. abyssinica could benefit from the findings of this study. This is the first report on micropropagation of E. abyssinica.
\end{abstract}

Due to either limited availability or affordability of pharmaceutical medicines, two-third of the world population (mainly in the developing countries) rely entirely on medicinal plants as their primary source of health care (Ayyanar and Ignacimuthu, 2008; Kamanula et al., 2011; Okpuzor et al., 2008). Increased interest in medicinal plants as a reemerging health aid has been fuelled by the rising costs of prescription drugs in the maintenance of personal health and well-being, and the bioprospecting of new plant-derived drugs. It is predicted that in Sub-Saharan Africa, $80 \%$ of the rural population depends on plant traditional remedies (Hoareau and Edgar, 1999).

Currently, medicinal plants are harvested in an unregulated manner from natural stands (Titanji et al., 2008; Zschocke et al., 2000). This puts pressure on natural populations, severely compromising their contribution to health care (Wynberg, 2002). Indeed, the upsurge in market and public demand for medicinal plants exhibits the important risks to medicinal plants today. These include extinction as well as loss of genetic diversity (Hoareau and Edgar, 1999). One such plant in dire need for conservation is E. abyssinica which is a veritable multipurpose tree. Many of Erythrina species are used indigenously as traditional medicines to treat various diseases, such as infections, cough, malaria, inflammation, bronchitis, asthma, and insomnia (Cui et al., 2008). The bark is commonly used in traditional medicine, to treat ulcers, snakebites, sexually transmitted diseases such as syphilis and gonorrhea, amoebiasis, liver inflammation, stomach-ache, colic, and measles (Yenesew et al., 2004). Alkaloids, benzofurans, flavonoids, chalcone, and other pterocarpans which possess a wide range of antioxidant, antimicrobial, cytotoxic, and anti-inflammatory activity have been reported as constituents of this genus (Nguyen et al., 2009). The foliage is considered a good protein supplement for ruminants (cattle, sheep, and goats) and has also been used as a fodder source for rabbits and pigs (Kass et al., 1993). In Ethiopia, resource-poor farmers with stall-fed sheep and goats used leafy twigs effectively as a cheap source of protein supplement for low-quality diets during the dry season (Aerts, 2008). The roots of trees are infected by rhizobia nodulate and fix atmospheric nitrogen. Nitrogen is the most important nutrient in seedlings mulched with $E$. abyssinica (Anthofer et al., 1997).

The conventional methods used in the propagation of $E$. abyssinica produce a high degree of genetic variability and consequently decrease the medicinal value of the plant. Besides, the seeds have a low germination rate (Aerts, 2008); furthermore, propagation is restricted to rainy season (Sarasan et al., 2011). On the other hand, micropropagation offers a rapid means of producing large quantity of clonal planting stocks and propagation of some commercial crops and also tree species that are difficult to establish conventionally (Bonga, 1987; Merkle and Dean, 2000; Thorpe et al., 1990). Micropropagation of a wide range of tree species have been successfully achieved (Pankaj and Toshiyuki, 2001). However, numerous recalcitrant forest trees of economic value are still difficult to propagate in vitro (Anna et al., 2010).

There are no documented studies on the micropropagation of E. abyssinica. Consequently, there is need to develop mass propagation protocols which produces true to type plants irrespective of season. This would 
meet demand for planting materials as well as reduce pressure on natural stands. Such technologies include in vitro propagation techniques that provide a platform for effective propagation of endangered plants.

\section{Methods}

Plant materials. The study was carried out at the Plant Tissue Culture laboratory of the Coffee Research Foundation located in Ruiru (1620 $\mathrm{m}$ a.s. $\left.11^{\circ} 06^{\prime} \mathrm{S} ; 36^{\circ} 45^{\prime} \mathrm{E}\right)$, Kenya. The seeds used in this study were obtained from a demonstration plot at Kenyatta University.

Seed sterilization. The seeds were washed with tap water containing a few drops of liquid detergent Teepol (Reckitt and Benckiser Ltd, Nairobi, Kenya) and rinsed two times. They were then transferred to the lamina flow cabinet, immersed in $70 \%(\mathrm{v} / \mathrm{v})$ ethanol for $10 \mathrm{~min}$ and rinsed twice with sterile distilled water. Thereafter, they were subjected to sterilization using varying concentrations $(10 \%, 20 \%$, and $30 \%)$ of a commercial bleach (JIK) which contains $3.85 \%$ sodium hypochlorite $(\mathrm{NaOCl})$ for $25 \mathrm{~min}$.

Table 1. Effects of different JIK concentrations on elimination of surface contamination from E. abyssinica seeds after 4,8 , and $12 \mathrm{~d}$.

\begin{tabular}{lcccc}
\hline Concn of JIK (\% v/v) & No. of days & Initial no. of seeds & Contaminated seeds & Percent $(\%)$ clean seed \\
\hline 10 & 4 & 20 & 0 & 100 \\
& 8 & 20 & 8 & 60 \\
20 & 12 & 20 & 9 & 55 \\
& 4 & 20 & 4 & 80 \\
& 8 & 20 & 14 & 30 \\
30 & 12 & 20 & 15 & 25 \\
& 4 & 20 & 10 & 70 \\
& 8 & 20 & 10 & 50 \\
\hline
\end{tabular}
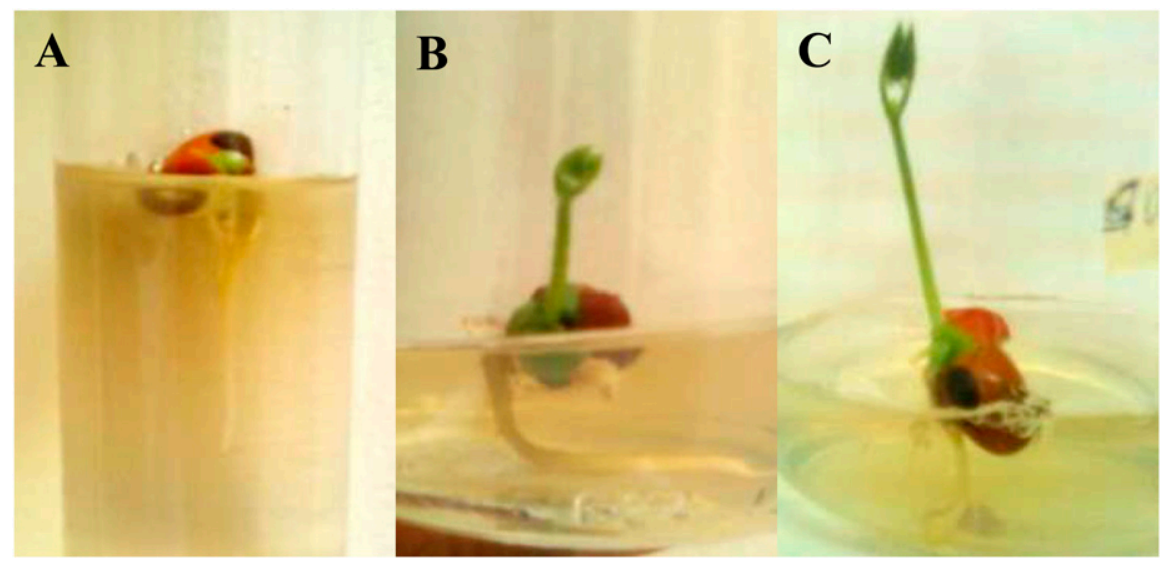

Fig. 1. Seeds germination after (A) $4 \mathrm{~d}$, (B) $8 \mathrm{~d}$, and (C) $12 \mathrm{~d}$.
Germination of seeds. The sterilized seeds were germinated on MS media supplemented with 3\% sucrose and incubated in a growth room at $25 \pm 2{ }^{\circ} \mathrm{C}$ and 16 -h photoperiod for 1 month.

Preparation of medium. The media used for germinating seeds was prepared using Murashige and Skoog (1962) (MS) basal salts. On the other hand, for regeneration of microshoot, the MS media was supplemented with $3 \%(\mathrm{w} / \mathrm{v})$ sucrose, BAP evaluated at $2.15,4.30,6.46$, and $8.61 \mathrm{mg} / \mathrm{L}$, and kinetin at $2.25,4.50,6.75$, and $9.0 \mathrm{mg} / \mathrm{L}$ in separate experiments. Rooting of microshoots was evaluated on half-strength MS media supplemented with IBA 2.25, 4.50, 6.75, and 9.0 $\mathrm{mg} / \mathrm{L}$. The $\mathrm{pH}$ was adjusted to 5.8 using $0.1 \mathrm{~m}$ $\mathrm{HCl}$ or $0.1 \mathrm{NaOH}$ and the media was gelled with $0.3 \%$ phytagel. The media was dispensed in $10 \mathrm{~mL}$ aliquots into test tubes and then autoclaved at $1.06 \mathrm{~kg} \cdot \mathrm{cm}^{-2}$ and $121{ }^{\circ} \mathrm{C}$ for $15 \mathrm{~min}$.

Inoculation and incubation. Nodal explants were harvested from the in vitro germinated seedlings and inoculated on the microshoot regeneration media under evalu- ation. All in vitro manipulations were carried out under sterile conditions in a laminar airflow hood in the laboratory. The regenerated microshoots were excised and cultured on the rooting media under evaluation. While working under the cabinet, sterilization of the work surface was achieved by spraying with $70 \%(\mathrm{v} / \mathrm{v})$ ethanol in-between operations. All cultures were incubated in a growth room maintained at $25 \pm 2{ }^{\circ} \mathrm{C}$ and 16-h photoperiod.

Transplanting. The regenerated plantlets were carefully removed from the test tubes after 2 months and the roots gently cleaned with running tap water to remove agar. The plants were then carried to the green house where they were treated with $2 \%$ fungicide (Redomil for $20 \mathrm{~min}$ ). A weaning pot (Supplied by Sunpalm Australia PTY, Ltd.) was filled with sterile potting mixture top soil, sand, and manure mixed in the ratio of $3: 2: 1$ (w/w). The pot was immersed in a basin containing water to allow the potting mixture soak water until the top was moist. The pot was then removed from the basin and the plantlets carefully transplanted using sharp wooden sticks. After 2 weeks, the holes of the weaning pot were half-way opened and eventually fully opened after 1 month. The plants were irrigated every week with tap water using a hand sprayer.

Data collection. Collection of data on the number of clean cultures after sterilization commenced $4 \mathrm{~d}$ after culturing and continued on a weekly interval for 4 weeks. Data collected on sterilization was converted to percentage. For the regeneration of microshoot, assessment of the number of microshoots and their length was carried out 1 week after inoculation and on weekly interval for 4 weeks during incubation. The number of roots per microshoot and their lengths were assessed after 1 week and continued for 4 weeks. While in the glasshouse the number of surviving plantlets was recorded.

Experimental design and data analysis. The experiments were laid out in completely randomized design (CRD) with 20 explants per treatment. The experiment was repeated three times. Data were subjected to ANOVA to test the significance of the difference between treatments using SAS packages. Means separation were tested using the Least Significant Difference at $P<0.05$. The results are expressed as a mean \pm SE.

\section{Results and Discussion}

Surface sterilization of seeds. There was no contamination recorded in the first $4 \mathrm{~d}$

Table 2. Effect of different kinetin concentrations on shoot proliferation and growth.

\begin{tabular}{|c|c|c|c|c|c|c|c|c|}
\hline \multirow{2}{*}{$\begin{array}{l}\text { Concn of } \\
\text { kinetin } \\
(\mathrm{mg} / \mathrm{L})\end{array}$} & \multicolumn{2}{|c|}{7 Days } & \multicolumn{2}{|c|}{14 Days } & \multicolumn{2}{|c|}{21 Days } & \multicolumn{2}{|c|}{28 Days } \\
\hline & $\begin{array}{c}\text { Mean no. } \\
\text { shoots/explant }\end{array}$ & $\begin{array}{c}\text { Mean shoot } \\
\text { length }(\mathrm{cm}) \pm \mathrm{SE}\end{array}$ & $\begin{array}{c}\text { Mean no. } \\
\text { shoots/explant } \pm \text { SE }\end{array}$ & $\begin{array}{c}\text { Mean shoot } \\
\text { length }(\mathrm{cm}) \pm \mathrm{SE}\end{array}$ & $\begin{array}{c}\text { Mean no. } \\
\text { shoots/explant } \pm \text { SE }\end{array}$ & $\begin{array}{c}\text { Mean shoot } \\
\text { length }(\mathrm{cm}) \pm \text { SE }\end{array}$ & $\begin{array}{c}\text { Mean no. } \\
\text { shoots/explant } \pm \text { SE }\end{array}$ & $\begin{array}{c}\text { Mean shoot } \\
\text { length }(\mathrm{cm}) \pm \mathrm{SE}\end{array}$ \\
\hline 2.25 & NIL & $0.75 \pm 0.22 \mathrm{a}$ & $1.44 \pm 0.24 \mathrm{a}$ & $1.72 \pm 0.34 \mathrm{a}$ & $1.89 \pm 0.35 \mathrm{a}$ & $2.05 \pm 0.36 \mathrm{a}$ & $2.11 \pm 0.42 \mathrm{a}$ & $2.28 \pm 0.42 \mathrm{a}$ \\
\hline 4.50 & NIL & $0.54 \pm 0.20 \mathrm{a}$ & $1.33 \pm 0.17 \mathrm{a}$ & $1.32 \pm 0.30 \mathrm{~b}$ & $2.10 \pm 0.46 \mathrm{a}$ & $1.73 \pm 0.37 \mathrm{a}$ & $2.30 \pm 0.58 \mathrm{a}$ & $2.02 \pm 0.41 \mathrm{a}$ \\
\hline 6.75 & NIL & $0.76 \pm 0.19 \mathrm{a}$ & $1.58 \pm 0.20 \mathrm{a}$ & $1.64 \pm 0.29 \mathrm{a}$ & $2.85 \pm 0.34 \mathrm{~b}$ & $2.07 \pm 0.36 \mathrm{a}$ & $3.00 \pm 0.22 \mathrm{~b}$ & $2.60 \pm 0.60 \mathrm{~b}$ \\
\hline 9.0 & NIL & $0.73 \pm 0.22 \mathrm{a}$ & $1.70 \pm 0.15 \mathrm{a}$ & $1.65 \pm 0.37 \mathrm{a}$ & $2.70 \pm 0.34 \mathrm{~b}$ & $2.27 \pm 0.44 \mathrm{a}$ & $3.10 \pm 0.38 \mathrm{~b}$ & $2.65 \pm 0.47 \mathrm{~b}$ \\
\hline
\end{tabular}

Values represent means \pm SE. Means within a column followed by different letters are significantly different at $P<0.05$. 
Table 3. Effect of different concentrations of benzylaminopurine (BAP) on microshoot proliferation and growth.

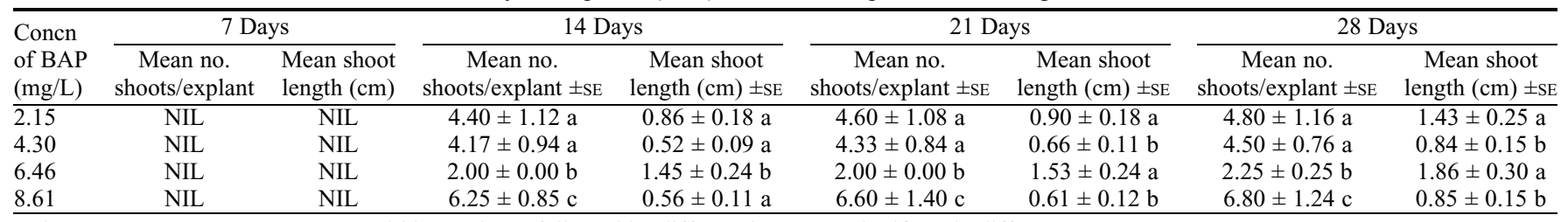

Values represent means \pm SE. Means within a column followed by different letters are significantly different at $P<0.05$.

Table 4. Effect of different concentrations of indolebutyric acid (IBA) on root regeneration from microshoots derived from kinetin containing media.

\begin{tabular}{|c|c|c|c|c|c|}
\hline $\begin{array}{l}\text { Shoots obtained from: Media } \\
\text { supplemented with kinetin }(\mathrm{mg} / \mathrm{l})\end{array}$ & $\begin{array}{l}\text { IBA concn } \\
(\mathrm{mg} / \mathrm{L})\end{array}$ & $\begin{array}{l}\text { Mean root length } \\
\text { (cm) } 7 \mathrm{~d} \pm \mathrm{SE}\end{array}$ & $\begin{array}{l}\text { Mean root length } \\
(\mathrm{cm}) 14 \mathrm{~d} \pm \mathrm{SE}\end{array}$ & $\begin{array}{l}\text { Mean root length } \\
(\mathrm{cm}) 21 \mathrm{~d} \pm \mathrm{SE}\end{array}$ & $\begin{array}{l}\text { Mean root length } \\
(\mathrm{cm}) 28 \mathrm{~d} \pm \mathrm{SE}\end{array}$ \\
\hline \multirow{2}{*}{2.25} & 0.51 & - & $1.85 \pm 0.19 \mathrm{a}$ & $3.60 \pm 0.35 b$ & $4.53 \pm 0.43 \mathrm{a}$ \\
\hline & 0.20 & - & $2.80 \pm 0.29 \mathrm{~b}$ & $4.23 \pm 0.15 b$ & $5.10 \pm 0.44 \mathrm{a}$ \\
\hline \multirow{2}{*}{4.50} & 0.51 & - & $1.49 \pm 0.20 \mathrm{a}$ & $4.09 \pm 0.05 b$ & $5.24 \pm 0.29 \mathrm{c}$ \\
\hline & 0.20 & - & $1.78 \pm 0.27 \mathrm{a}$ & $3.61 \pm 0.48 b$ & $3.94 \pm 0.58 b$ \\
\hline 6.75 & 1.02 & - & $1.25 \pm 0.32 \mathrm{c}$ & $2.25 \pm 0.50 \mathrm{c}$ & $3.00 \pm 0.80 \mathrm{~d}$ \\
\hline \multirow[t]{3}{*}{9.0} & 1.02 & - & $0.8 \pm 0.09 \mathrm{c}$ & $1.18 \pm 0.27 \mathrm{c}$ & $2.2 \pm 0.33 \mathrm{f}$ \\
\hline & 0.51 & - & $0.2 \pm 0.01 \mathrm{~d}$ & $0.9 \pm 0.01 \mathrm{e}$ & $1.0 \pm 0.01 \mathrm{~g}$ \\
\hline & 0.20 & - & - & - & - \\
\hline
\end{tabular}

Values represent means \pm SE. Means within a column followed by different letters are significantly different at $P<0.05$.

Table 5. Effect of different concentrations of indolebutyric acid (IBA) on root regeneration from microshoots derived from benzylaminopurine (BAP) containing media.

\begin{tabular}{|c|c|c|c|c|c|}
\hline $\begin{array}{l}\text { Shoots obtained from: Media } \\
\text { supplemented with BAP }(\mathrm{mg} / \mathrm{L})\end{array}$ & IBA concn $(\mathrm{mg} / \mathrm{L})$ & $\begin{array}{l}\text { Mean root length } \\
\text { (cm) } 7 \mathrm{~d} \pm \mathrm{SE}\end{array}$ & $\begin{array}{l}\text { Mean root length } \\
(\mathrm{cm}) 14 \mathrm{~d} \pm \mathrm{SE}\end{array}$ & $\begin{array}{l}\text { Mean root length } \\
(\mathrm{cm}) 21 \mathrm{~d} \pm \mathrm{SE}\end{array}$ & $\begin{array}{l}\text { Mean root length } \\
(\mathrm{cm}) 28 \mathrm{~d} \pm \mathrm{SE}\end{array}$ \\
\hline \multirow{2}{*}{2.15} & 0.51 & - & - & $1.35 \pm 0.55 \mathrm{~b}$ & $2.4 \pm 0.90 \mathrm{~b}$ \\
\hline & 0.20 & - & - & - & - \\
\hline \multirow{2}{*}{4.30} & 0.51 & - & $0.63 \pm 0.12 \mathrm{a}$ & $1.33 \pm 0.07 \mathrm{~b}$ & $2.1 \pm 0.21 \mathrm{~b}$ \\
\hline & 0.20 & - & & & \\
\hline 6.46 & 1.02 & - & $0.50 \pm 0.15 \mathrm{a}$ & $0.70 \pm 0.12 \mathrm{a}$ & $0.90 \pm 0.08 \mathrm{c}$ \\
\hline \multirow[t]{3}{*}{8.61} & 1.02 & - & $0.78 \pm 0.14 \mathrm{a}$ & $0.83 \pm 0.17 \mathrm{a}$ & $1.00 \pm 0.14 \mathrm{c}$ \\
\hline & 0.51 & - & - & - & - \\
\hline & 0.20 & - & - & - & - \\
\hline
\end{tabular}

Values represent means \pm SE. Means within a column followed by different letters are significantly different at $P<0.05$.

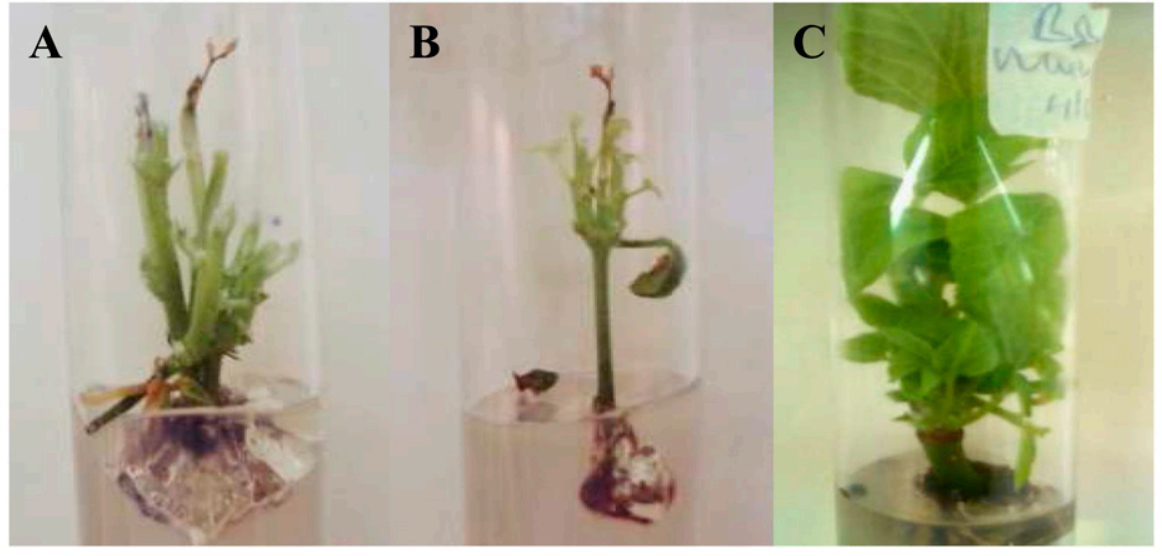

Fig. 2. Regeneration of E. abyssinica microshoots from nodal explants: (A) $7 \mathrm{~d}$, (B) $14 \mathrm{~d}$, and (C) $28 \mathrm{~d}$ after culture.

when the seeds were exposed to $10 \%$ JIK for a duration of $25 \mathrm{~min}$ (Table 1). On the other hand, the other treatments recorded low contamination during the same period. The highest number of clean seeds (55\%) was recorded after $12 \mathrm{~d}$ when seeds were subjected to sterilization with $10 \%$ JIK for 25 min. It is likely that the higher concentration of JIK had an effect on the seed coat allowing internal contamination.

Germination of seeds. The germination of seeds at 4, 8 , and $12 \mathrm{~d}$ after sowing in the MS media is shown in Figure 1A-C. The use of explants from mature plants growing in the field is not possible, mainly due to the high level of contamination, reduced or absence of morphogenetic ability (Bonga et al., 2010) and poor rooting of the regenerated shoots. On the other hand, the success in tissue culture depends on the effectiveness of the sterilization methods used on the explants before culture initiation (Yildiz and Celal, 2002). It follows that all the materials used in the plant cell culture must be sterilized to eliminate the microbial contaminants. One of the efficient ways of minimizing contamination in culture is the use of explants from aseptically germinated seedlings. The tissues can be isolated and used immediately (Gamborg and Phillips, 1995; Stephen et al., 1997). A commonly employed disinfectant in tissue culture is $\mathrm{NaOCl}$ which dates back to the 


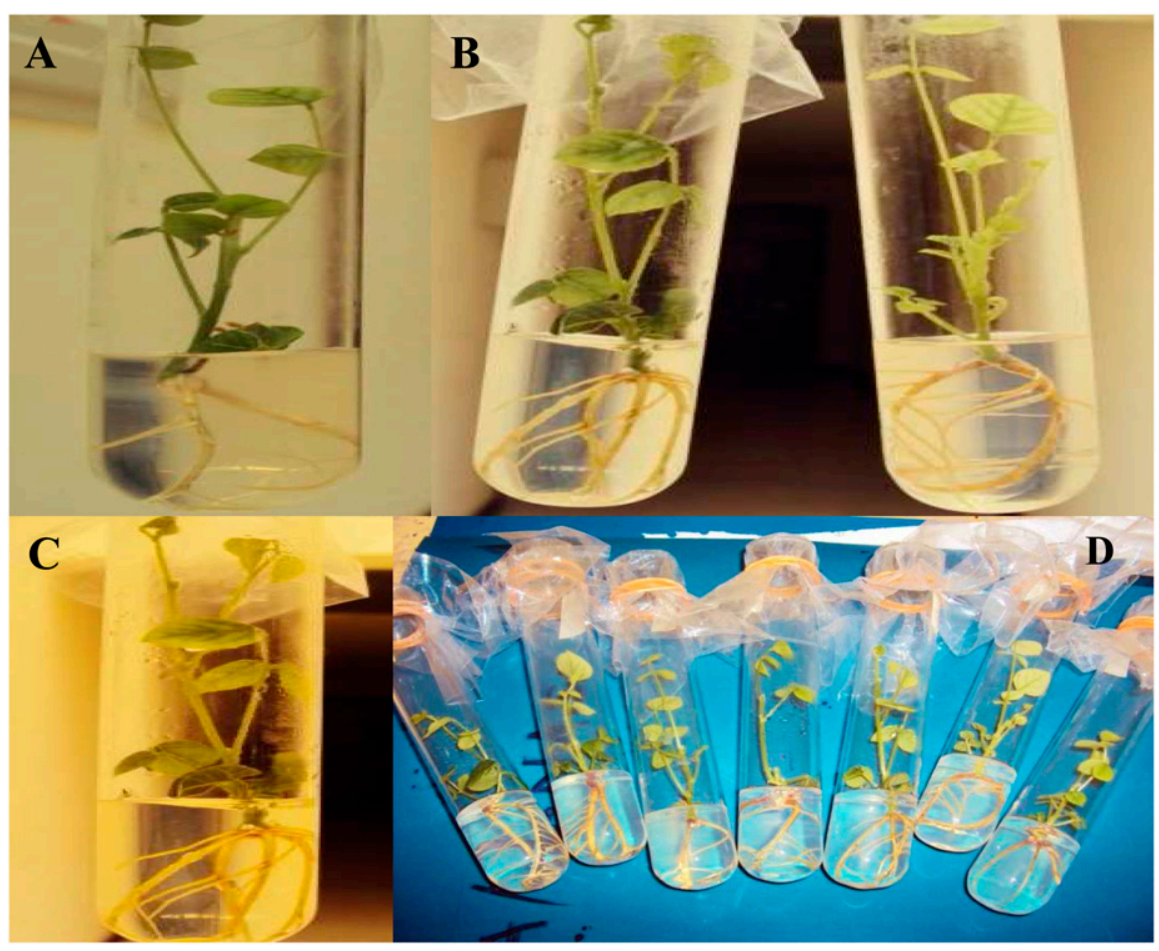

Fig. 3. Rooting of microshoots in kinetin augmented media: (A) $7 \mathrm{~d}$, (B) $14 \mathrm{~d}$, (C) $21 \mathrm{~d}$, and (D) $28 \mathrm{~d}$ after culture.

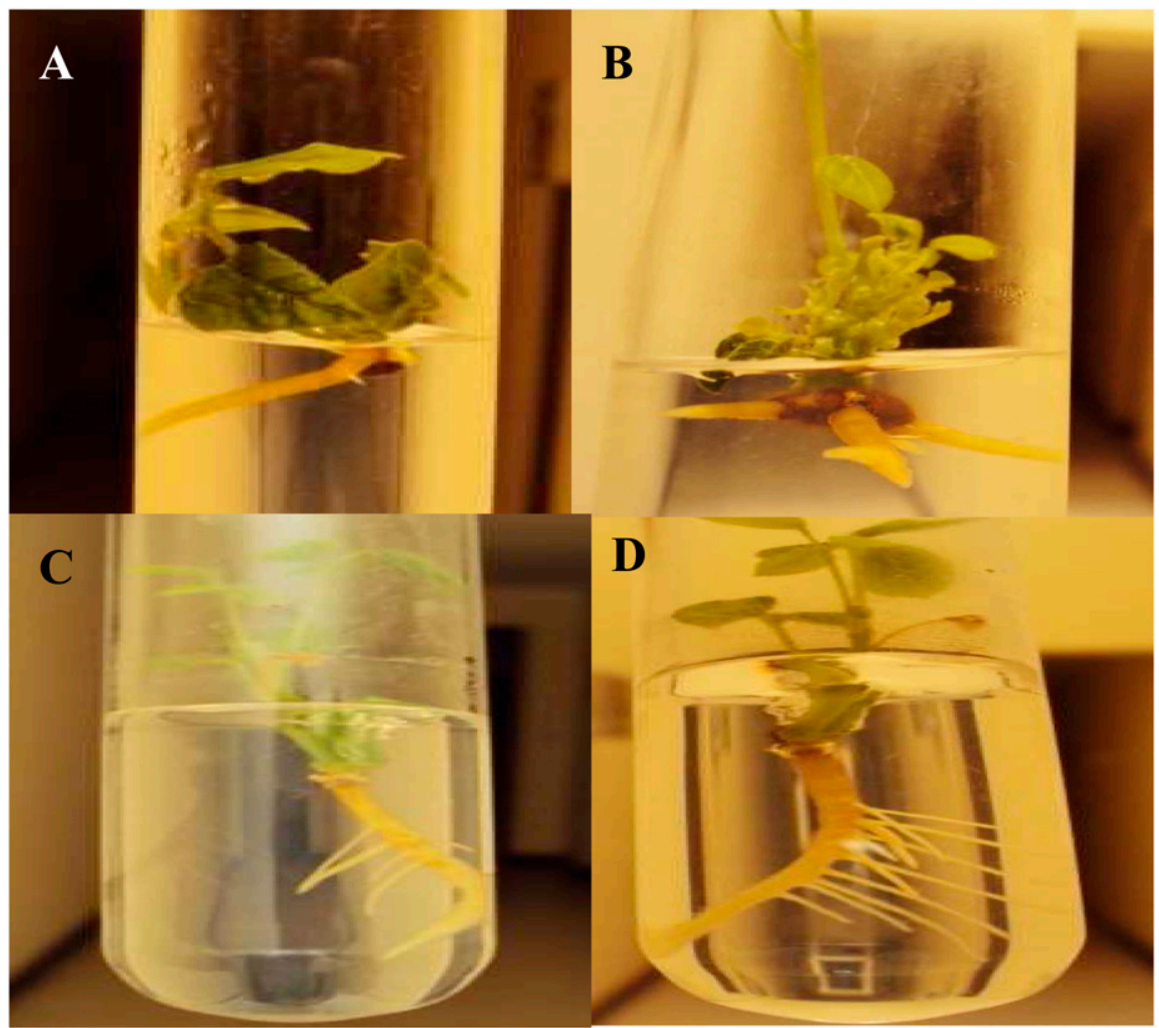

Fig. 4. Rooting of microshoots in benzylaminopurine-augmented media: (A) $7 \mathrm{~d}$, (B) $14 \mathrm{~d},(\mathbf{C}) 21 \mathrm{~d}$, and (D) $28 \mathrm{~d}$ after culture

mid-18th century. During this study, the surface sterilization of seeds was evaluated using the household bleach brand JIK [Reckitt and Benckiser (Kenya) Ltd.] which contains $3.85 \% \mathrm{NaOCl}$. The optimum sterilization
Effect of different kinetin concentrations on in vitro shoot proliferation from nodal explants. There were no microshoots regenerated at $4 \mathrm{~d}$ after culture (Table 2). The media supplemented with kinetin evaluated at $9.0 \mathrm{mg} / \mathrm{L}$ gave the highest $(3.10 \pm 0.38)$ mean number of shoots per explant and the highest mean height $(2.65 \pm 0.47 \mathrm{~cm})$ after $28 \mathrm{~d}$. However, these results were not significantly different from those obtained with $6.75 \mathrm{mg} / \mathrm{L}$ kinetin. Increasing the concentration of kinetin from 2.25 to $9.0 \mathrm{mg} / \mathrm{L}$ resulted in an increase of the number of microshoots and their lengths after $28 \mathrm{~d}$.

Effect of different BAP concentrations on in vitro shoot proliferation from nodal explants. There was no visible growth on $7 \mathrm{~d}$ after culture in all the BAP concentrations evaluated (Table 3). BAP evaluated at 8.61 $\mathrm{mg} / \mathrm{L}$ gave the highest $(6.80 \pm 1.24)$ mean number of microshoots after $28 \mathrm{~d}$ while BAP evaluated at $6.46 \mathrm{mg} / \mathrm{L}$ gave the lowest number $(2.25 \pm 0.25)$ microshoots per nodal explant. Figure $2 \mathrm{~A}-\mathrm{C}$ shows the regenerated microshoots from nodal explants cultured on MS media supplemented with BAP. The number of microshoots obtained with BAP evaluated at $8.61 \mathrm{mg} / \mathrm{L}$ was twice that achieved with the highest concentration of kinetin $(3.10 \pm 0.38)$. In tissue culture, plant growth regulators are critical media components in determining the developmental pathway of the plant cells. Cytokinins such as BAP and kinetin are generally known to reduce the apical meristem dominance and induce both axillary and adventitious shoots formation from meristematic explants in banana (Madhulatha et al., 2004). The results of the present investigation reveal that growth and proliferation of microshoots in E. abyssinica are under hormonal control; this corroborates the findings of Singh et al. (2009). During this study, BAP was found to be more effective than kinetin in inducing multiple shoots from the nodal explants. The number of microshoots obtained on media supplemented with high levels of BAP was double that obtained with the highest kinetin concentration evaluated. These results are in agreement with those of (Thoyajaksha and Rai, 2001; Waweru et al., 2011) who reported that the media supplemented with BAP yielded more microshoots than the media supplemented with kinetin in Dictyospermum ovalifolium and Cyphomandra betacea (Tamarillo), respectively.

Effect of different IBA on in vitro rooting of microshoots derived from kinetin supplemented media. The results of the induction of roots from microshoots derived from media supplemented with kinetin are presented in Table 4. There were no roots produced from all the microshoots obtained with the kinetin treatments in the first $7 \mathrm{~d}$. The lowest concentration of IBA $(0.20 \mathrm{mg} / \mathrm{L})$ did not produce any roots from microshoots derived from media supplemented with high concentration of kinetin (6.75 and $9 \mathrm{mg} / \mathrm{L})$. However, microshoots derived from media supplemented with 6.75 $\mathrm{mg} / \mathrm{L}$ kinetin treatment gave the longest mean 
root length $(6.00 \pm 1.85 \mathrm{~cm})$ after $28 \mathrm{~d}$ on the media with $0.51 \mathrm{mg} / \mathrm{L} \mathrm{IBA}$.

Effect of different IBA on in vitro rooting of microshoots derived from BAP supplemented media. The results of induction of roots from microshoots derived from media supplemented with BAP are presented in Table 5 . There was no regeneration of roots from the microshoots derived from media supplemented with BAP when the lower concentra-

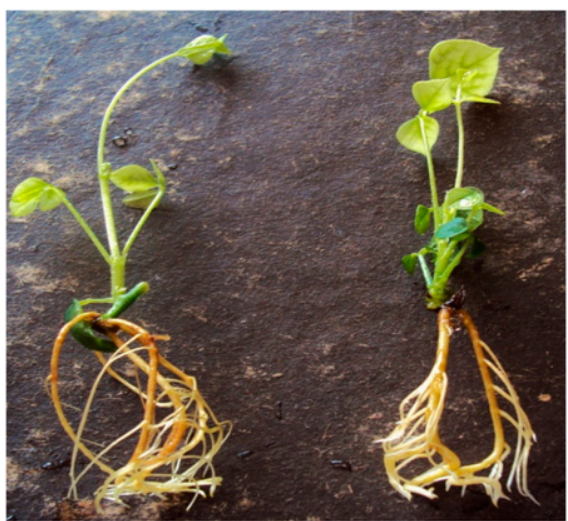

Fig. 5. In vitro regenerated plantlets ready for transplanting. tion of IBA $(0.20 \mathrm{mg} / \mathrm{L})$ was used. The longest root mean length $(2.4 \pm 0.90)$ was obtained when microshoots derived from media supplement with $2.15 \mathrm{mg} / \mathrm{L}$ BAP were cultured on $0.51 \mathrm{mg} / \mathrm{L}$ IBA. The roots obtained in microshoots sub-cultured from kinetin supplemented media were more branched and had more fibrous roots (Fig. $3 \mathrm{~A}-\mathrm{D})$. On the other hand, microshoots derived from BAP-supplemented media formed roots that were thick and a tap root (Fig. 4A-D). Auxins stimulate root initiation by activating quiescent pericycle cells to initiate division and then expansion which facilitate lateral root emergence, although response varies with concentration. Fukaki and Tasaka (2009) and Taiz and Zeiger (2003) reported that auxins are required for root induction, although, root growth is inhibited at higher auxin concentration. On the other hand, Kollmeier et al. (2000) stated that high auxin concentration inhibits root elongation. The microshoots obtained from media supplemented with kinetin had well developed roots which were long and with root hair. However, those obtained from BAP had short thick roots with few root hairs. Several reasons could be hypothesized; chemically stable cytokinins such as BAP control growth in vitro by modulating levels of endogenous ethylene

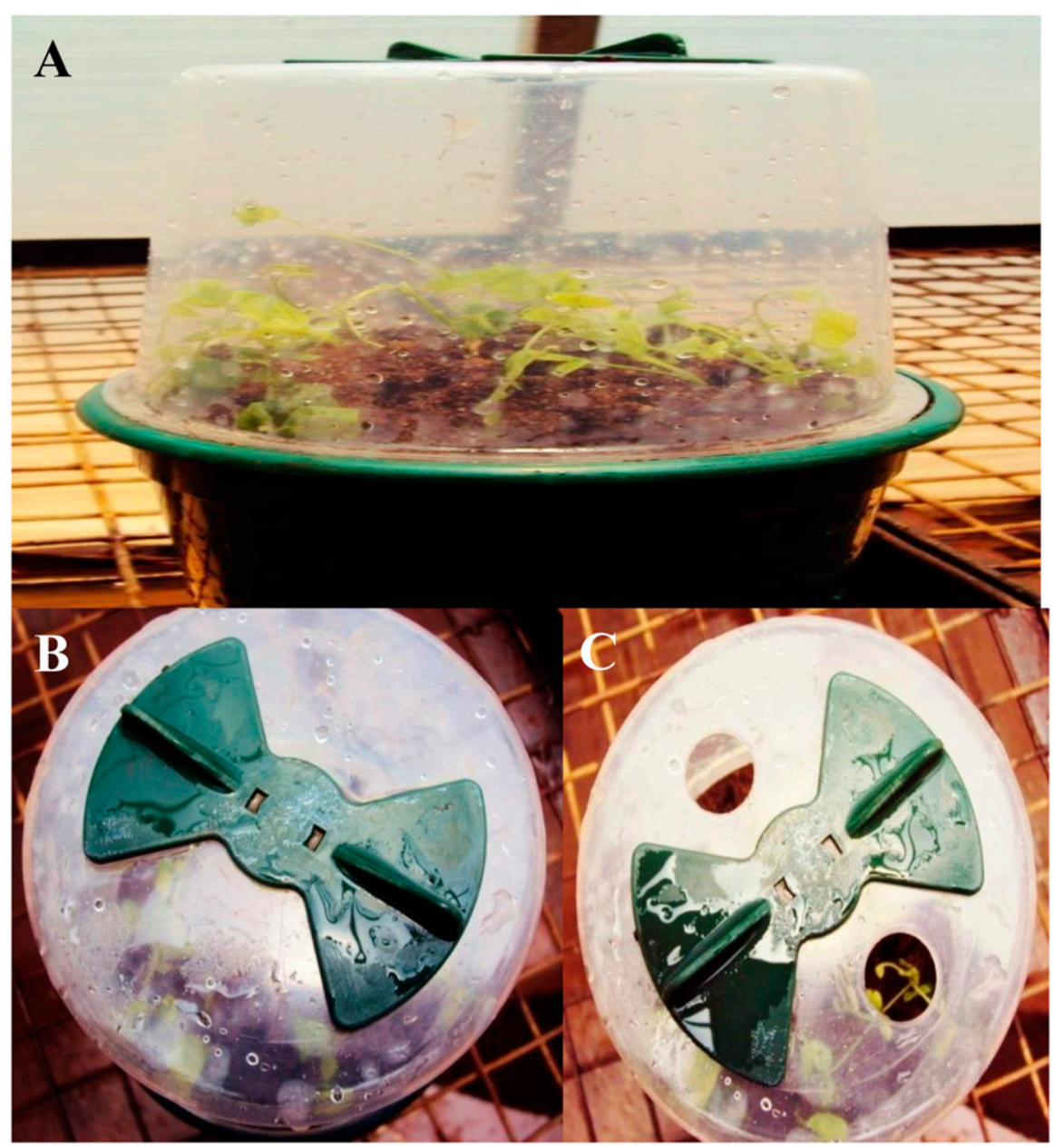

Fig. 6. Acclimatization of plantlets. (A) Weaning pot with plantlets; (B) the top of the pot showing closed holes; and (C) pots with opened holes after 1 month.

and auxin-cytokinin complexes. Also, high levels of hormones have been shown to inhibit growth in vitro through negative feedback mechanisms (Hutchinson and Saxena, 1996; Trewavas, 1981). It is conceivable that high levels of BAP resulted in elevation of endogenous ethylene as well as auxincytokinin levels which have been reported to retard root elongation and branching (Cary et al., 1995; Skoog and Miller, 1957).

Acclimatization. The regenerated plantlets (Fig. 5) were planted in a weaning pot and the two holes on the cover were kept closed for the first 2 week and eventually fully opened after 1 month (Fig. 6A-C). At the end of 4 weeks in the greenhouse, a survival rate of $65 \%$ of the in vitro regenerated plantlets was recorded and the plants were seen to be growing vigorously.

\section{Conclusion}

This study clearly demonstrates that $E$. abyssinica is amenable to micropropagation technique. There is however need to study field performance and the medicinal content of the in vitro regenerated plantlets. With the increasing worldwide demand for medicinal plants as an alternative to prescription drugs, ex situ, in situ conservation programs and true to type mass propagation of E. abyssinica could benefit from our findings.

\section{Literature Cited}

Aerts, R. 2008. Erythrina abyssinica Lam. ex DC. In: D. Louppe, A.A. Oteng-Amoako, and M. Brink (eds.). Prota 7(1): Timbers/Bois d'œuvre 1. [CDRom]. PROTA, Wageningen, The Netherlands.

Anna, P., R. Caniato, E.M. Cappelleti, and R. Filippini. 2010. Organogenesis from shoot segments and via callus of endangered Kosteletzkyapentacarpos (L.) Ledeb. Plant Cell Tissue Organ Cult. 100:309-315.

Anthofer, J., J. Hanson, and S.C. Jutzi. 1997. Plant nutrient supply from nine agroforestry tree species to wheat (Triticum aestivum) analysed by vector diagnosis. J. Agron. Crop Sci. 179:75-82.

Ayyanar, M. and S. Ignacimuthu. 2008. Endemic medicinal plants used by tribal people in Tirunelveli hills, Western Ghats of India. Wildlife biodiversity conservation. Daya Publishing House, New Delhi. p. 278-285.

Bonga, J.M., K. Klimaszewska, and P. Von Aderkas. 2010. Recalcitrance in clonal propagation, in particular of conifers. Plant Cell Tissue Organ Cult. 100:241-254.

Bonga, J.M. 1987. Clonal propagation of mature trees: Problems and possible solutions, p. 249271. In: J.M. Bonga and D.J. Durzan (eds.). Cell and tissue culture in forestry: General principles and biotechnology. Vol. 1. Martinus Nijhoff Publishers, Dordrecht, The Netherlands.

Cary, A.J., W. Liu, and S.H. Howell. 1995. Cytokinin action is coupled to ethylene in its effects on the inhibition of root and hypocotyl elongation in Arabidopsis thaliana seedlings. Plant Physiol. 107:1075-1082.

Cui, L., P.T. Thuong, H.S. Lee, D.T. Ndinteh, and J.T. Mbafor. 2008. Flavanones from the stem bark of Erythrina abyssinica. Bioorg. Med. Chem. 16:10356-10362.

Fukaki, H. and M. Tasaka. 2009. Hormone interactions during lateral root formation. Plant Mol. Biol. 69:437-449. 
Gamborg, O.L. and G.C. Phillips. 1995. Sterile Techniques, p. 35-42. In: O.L. Gamborg and G.C. Phillips (eds.). Plant Cell, Tissue and Organ Culture. Springer-Verlag Berlin, Heidelberg, NY.

Hoareau, L. and J.D. Edgar. 1999. Medicinal plants: A re-emerging health aid. Electron. J. Biotechnol. 2(2). ISSN: 0717-3458.

Hutchinson, M.J. and P.K. Saxena. 1996. Role of purine metabolism in thidiazuron-induced somatic embryogenesis of geranium (Pelargonium $\times$ hortorum) hypocotyl cultures. Physiol. Plant. 98:517-522

Kamanula, J., G.W. Sileshi, S.R. Belmain, P. Sola, B.M. Mvumi, G.K.C. Nyirenda, S.P.N. Nyirenda, and P.C. Stevenson. 2011. Farmers' insect pest management practices and pesticidal plant use for protection of stored maize and beans in Southern Africa. Intl. J. Pest Mgt. 57:41-49.

Kass, D.L.J., J. Jimenez, M.L. Sanchez, Soto, and H. Garzon. 1993. Erythrina in alley farming. In: S.B. Westley and M.H. Powell (eds.). Erythrina in the new and old worlds. NFTA, Paia, HI (In press).

Kollmeier, M., H.H. Felle, and W.J. Horst. 2000. Is basipetal auxin flow involved in inhibition of root elongation? Plant Physiol. 122:945-956.

Madhulatha, P., M. Anbalagan, S. Jayachandran, and N. Sakthivel. 2004. Influence of liquid pulse treatment with growth regulators on in vitro propagation of banana (Musa spp. AAA). Plant Cell Tissue Organ Cult. 76:189-192.

Maina, S.M., Q. Emongor, K.K. Sharma, S.T. Gichuki, M. Gathaara, and S.M. de Villiers. 2010. Surface sterilant effect on the regeneration efficiency from cotyledon explants of groundnut (Arachis hypogea L.) varieties adapted to eastern and Southern Africa. Afr. J. Biotechnol. 9(20):2866-2871.

Merkle, S.A. and J.F.D. Dean. 2000. Forest tree biotechnology. Curr. Opin. Biotechnol. 11:298302.
Murashige, T. and F. Skoog. 1962. A revised medium for rapid growth and bioassays with tobacco tissue cultures. Physiol. Plant. 15:473497.

Nguyen, P.H., T.V.T. Le, P.T. Thuong, T.T. Dao, and D.T. Ndinteh. 2009. Cytotoxic and PTP1B inhibitory activities from Erythrina abyssinica. Bioorg. Med. Chem. Lett. 19:6745-6749.

Okpuzor, J., O. Adebesin, H. Ogbunugafor, and I. Amadi. 2008. The potential of medicinal plants in sickle cell disease control: A Review. Intl. J. Biomed. Health Sci. 4:47-55.

Pankaj, K.B. and M. Toshiyuki. 2001. Novel micro propagation system: A review. Pak. J. Biol. Sci. 4(2):117-120.

Sarasan, V., G.C. Kite, G.W. Sileshi, and P.C. Stevenson. 2011. Applications of phytochemical and in vitro techniques for reducing overharvesting of medicinal and pesticidal plants and generating income for the rural poor. Plant Cell Rpt. 30(7):1163-1172.

Singh, S.K., M.K. Rai, P. Asthana, and L. Sahoo. 2009. An improved micropropagation of Spilanthes acmella L through transverse thin layer culture. Acta Physiol. Plant. 31:693698.

Skoog, F. and C.O. Miller. 1957. Chemical regulation of growth and organ formation in plant tissue cultured in vitro. Symp. Soc. Expt. Biol. 11:118-131.

Stephen, C.B., S. Kirk, and S. Brian. 1997. Plant regeneration using tissue culture and Agrobacterium tumifaciens transformation. Roger Williams University College of the Arts and Sciences, Bristol, RI.

Taiz, L. and E. Zeiger. 2003. Auxins, p. 623. In: J.S. Heslop-Harrison and D. Frost (eds.). Plant Physiology. Macmillan Publishing Co., New York.

Thorpe, T.A., I.S. Harry, and P.P. Kumar. 1990. Application of micropropagation to forestry. In: P.C. Debergh and R.H. Zimmerman (eds.).
Micropropagation. Kluwer Academic Publishers, Dredrecht, The Netherlands.

Thoyajaksha, C.M. and V.R. Rai. 2001. In vitro micropropagation of Dictyospermum ovalifolium Wight, a rare and endemic medicinal plant in Western Ghats India. Plant Cell Biotechnol. Mol. Biol. 2:57-62.

Titanji, V.P.K., D. Zofou, and M.N. Ngemenya. 2008. The antimalarial potential of medicinal plants used for the treatment of malaria in Cameroonian folk medicine. Afr. J. Tradit. Complement. Altern. Medicines 5:302-321.

Trewavas, A.J. 1981. How do plant growth substances work? Plant Cell Environ. 4: 203-228.

Waweru, B., I.J.K. Rodrigue, B. Kagiraneza, P.Y. Kanze Sallah, V. Ahishakiye, S. Kalisa, T. Asiimwe, J. Kahia, and D. Gahakwa. 2011. In vitro plant regeneration of Cyphomandra betacea (Tamarillo) through nodal culture. Rwanda J. Series E, Agr. Sci. 24:58-66.

Wynberg, R. 2002. A decade of biodiversity conservation and use in South Africa: Tracking progress from the Rio Earth Summit to the Johannesburg World Summit on Sustainable Development. S. Afr. J. Sci. 98:233243.

Yenesew, A., M. Induli, S. Derese, J.O. Midiwo, and M. Heydenreich. 2004. Anti-plasmodial flavonoids from the stem bark of Erythrina abysinica. Phytochemistry 65:3029-3032.

Yildiz, M. and E. Celal. 2002. The effect of sodium hypochlorite solution on in vitro seedling growth and shoot regeneration of flax (Linus usitatissimum). Nat. Products J. 2(4): 328-331.

Zschocke, S., T. Rabe, J.L. Taylor, A.K. Jager, and J. van Staden. 2000. Plant part substitution-a way to conserve endangered medicinal plants? J. Ethnopharmacol. 71:281 292. 